\title{
K Osnovna šola za odrasle na ljudskih univerzah
}

\author{
Diana Roškar
}

Osnovnošolsko izobraževanje za odrasle je namenjeno zaposlenim ter tudi nezaposlenim odraslim in mladostnikom, ki želijo končati osnovno šolo. Eden temeljnih ciljev osnovnega izobraževanja je usposabljanje za nadaljnje izobraževanje in samoizobraževanje.

Udeleženci osnovne šole za odrasle si pridobijo temeljno znanje iz maternega jezika, matematike, družboslovnih in naravoslovnih predmetov ter glasbene in likovne vzgoje. Izpopolnjujejo svojo splošno izobrazbo ter razvijajo intelektualne sposobnosti, ustvarjalnost, kritičnost, samostojnost, se socializirajo ter se osebnostno hitreje razvijajo.

Na Zvezi ljudskih univerz Slovenije, ki združuje 41 članic ljudskih univerz, redno spremljamo vse novosti, povezane $\mathrm{z}$ osnovnošolskim izobraževanjem za odrasle, vzdržujemo stalne stike $\mathrm{z}$ Zavodom RS za šolstvo ter Ministrstvom RS za šolstvo in šport, spremljamo kurikularno prenovo, dajemo pobude, predloge itd. Redno spremljamo tudi statistične podatke o številu udeležencev, ki se vključujejo v program osnovnošolskega izobraževanja na ljudskih univerzah.

$\mathrm{V}$ nadaljevanju želim predstaviti nekatere statistične podatke podatke, ki so izredno pomembni tudi za kurikularno prenovo.

\section{1. Šłevilo udeležencev v osnovni šoli zø odrasle v šolskem lełu 1990/91-1926/97}

Zanimanje za vpis v osnovno šolo za odrasle je vsako leto večji, saj sta se v zadnjih petih letih povečala število oddelkov in tudi uspešnost udeležencev (za približno 10\%) - to je razvidno iz grafa 1 .

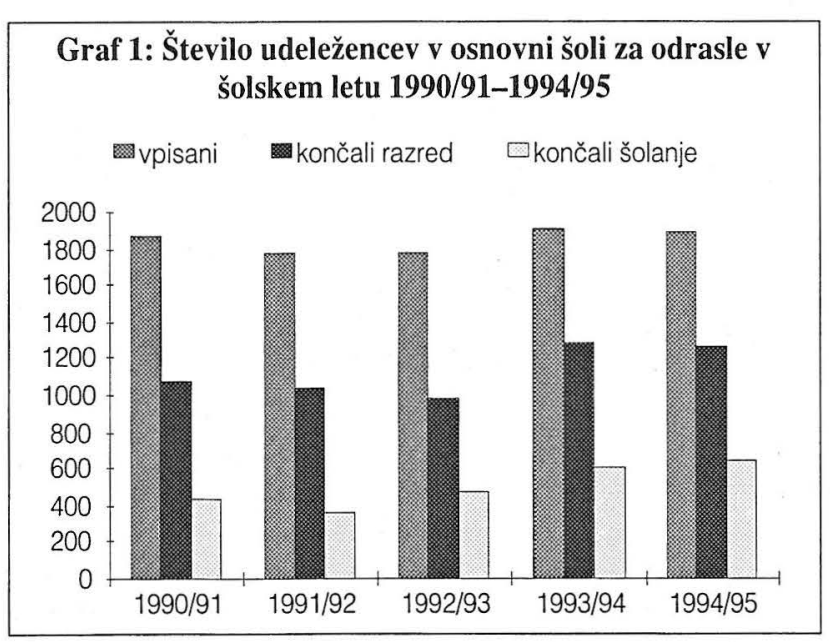

Vsak semester, jesenski in tudi spomladanski, ljudske univerze vpisujejo v program osnovne šole za odrasle. $V$ jesenskem semestru šolskega leta 1996/97 poteka osnovnošolsko izobraževanje na 32 ljudskih univerzah in v eni redni osnovni šoli. V 95 rednih in mešanih oddelkov se je vpisalo 1.369 udeležencev. Največ zanimanja za vpis je predvsem v večjih krajih, kjer vlada na trgu delovne sile tudi večja konkurenca: 33,90\% udeležencev je bilo vpisanih v ljubljanskih LU, 9,28\% v AZ -LU Maribor, 6,21\% na LU Celje, 4,67\% na LU Jesenice - tabela.

Pouk v osnovnih šolah za odrasle se začne v septembru ali oktobru in se navadno konča kasneje kot v rednih osnovnih šolah. Zato se pojavi problem $v$ zvezi z zunanjim preverjanjem znanja, ki poteka sočasno za vse, za tiste iz rednih osnovnih šol in za tiste iz osnovnih šol za odrasle. Mladina, ki je zelo motivirana za to, da bi končala osnovnošolski program, in se želi vpisati v srednješolske programe, obiskuje predavanja tudi med prazniki, če je treba.

\begin{tabular}{|c|c|c|c|}
\hline ZAP. & LJUDSKA & ŠT. DISLOCIRANIH & ŠT. \\
\hline ŠTEV. & UNIVERZA & ENOT & VPISANIH \\
\hline 1 & AJDOVŠČINA & 1 & 11 \\
\hline 2 & CELJE & 5 & 85 \\
\hline 3 & ČRNOMELJ & 3 & 29 \\
\hline 4 & GORNJA RADGONA & 1 & 16 \\
\hline 5 & IDRIJA & 1 & 9 \\
\hline 6 & JESENICE & 5 & 64 \\
\hline 7 & KOČEVJE & 2 & 25 \\
\hline 8 & KOPER & 4 & 61 \\
\hline 9 & KRANJ & 4 & 55 \\
\hline 10 & KRŠKO & 1 & 16 \\
\hline 11 & LENART & 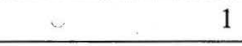 & 16 \\
\hline 12 & LJ. - CENE ŠTUPAR & 15 & 202 \\
\hline 13 & LJ. - UNIVERZUM & 5 & 112 \\
\hline 14 & LJ. - MIKLOŠIČ & 8 & 150 \\
\hline 15 & LJUTOMER & 1 & 19 \\
\hline 16 & MARIBOR & 9 & 127 \\
\hline 17 & MURSKA SOBOTA & 1 & 22 \\
\hline 18 & NOVA GORICA & 1 & 14 \\
\hline 19 & NOVO MESTO & 3 & 36 \\
\hline 20 & POSTOJNA & 2 & 23 \\
\hline 21 & PTUJ & 1 & 16 \\
\hline 22 & RADOVLJICA & 2 & 29 \\
\hline 23 & RAVNE & 2 & 39 \\
\hline 24 & SEŽANA & 1 & 20 \\
\hline 25 & SLOV. BISTRICA & 1 & 8 \\
\hline 26 & ŠKOFJA LOKA & 3 & 45 \\
\hline 27 & ROGAŠKA SLATINA & 3 & 15 \\
\hline 28 & TRBOVLJE & 1 & 18 \\
\hline 29 & TREBNJE & 4 & 35 \\
\hline 30 & TRŽIČ & 2 & 27 \\
\hline 31 & VELENJE & 1 & 11 \\
\hline \multirow[t]{2}{*}{32} & ŽALEC & 1 & 14 \\
\hline & SKUPAJ & 95 & 1369 \\
\hline
\end{tabular}

Tabela: Število udeležencev $v$ osnovni šoli za odrasle $v$ šolskem letu 1996/97 (jesenski semester) 


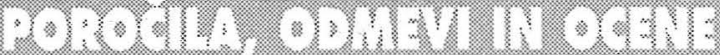

\section{2. Šłevilo udeležencev v posameznih razredih osnovne šole za odrasle v šolskem lełu 1990/91-1994/95}

Nedokončana osnovna šola je pri mladostnikih predvsem posledica slabih izkušenj pri izobraževanju, vplivov okolja, kaže pa se zlasti v odklonilnem odnosu mladostnikov do izobraževanja nasploh. Na ljudskih univerzah ugotavljamo, da se je populacija, ki se vpisuje v osnovno šolo za odrasle, v zadnjih letih bistveno spremenila. Največ vpisa je v VII. in VIII: razred (približno $88,5 \%$ ). Precej manj je vpisa v IV., V., in VI. razred, v zadnjih letih pa se ponovno kaže tudi zanimanje za vpis v najnižje razrede, kar je razvidno iz grafa 2.

\section{Graf 2: Število udeležencev v posameznih razredih v os-} novni šoli v šolskem letu 1990/91-1994/95

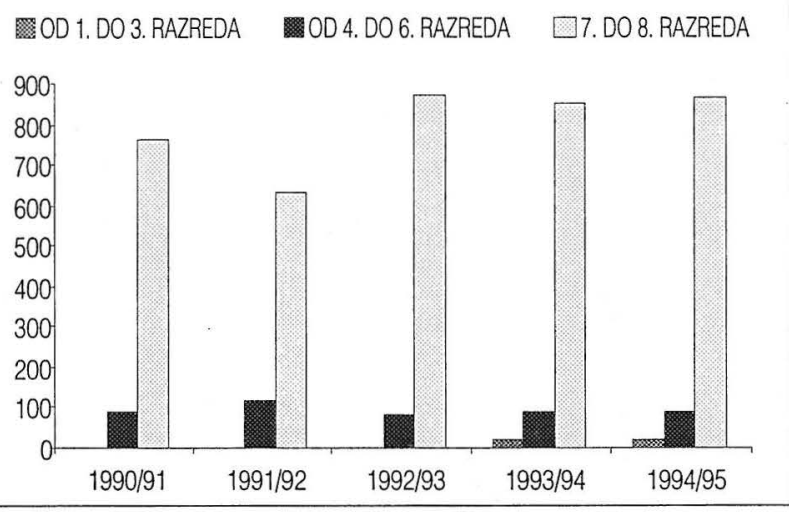

\section{Sfarrosthna strukłura udeležencev $v$ osnovni šoli za odrasle}

Število mladih, starih od 15 do 18 let, ki uspešno končajo osnovnošolsko izobraževanje na ljudskih univerzah, iz leta $\mathrm{v}$ leto narašča. To so večinoma udeleženci, ki se sami odločijo, da bodo končali osnovno šolo oziroma jih $\mathrm{k}$ temu usmerijo svetovalne službe v rednih osnovnih šolah, pa tudi zavodi za zaposlovanje. Ti udeleženci potrebujejo svetovalno službo tudi na ljudskih univerzah, žal pa šolska zakonodaja tega ne predvideva. Tako imajo na ljudskih univerzah navadno pogodbeno zaposlene razne svetovalne delavce, izjemoma pa te strokovnjake tudi redno zaposlijo.

Graf 4 nam kaže, da je bilo v šolskem letu 1994/95, od skupno 1261 udeležencev, ki so končali osnovno šolo za odrasle in mladostnike, kar 74\% udeležencev, starih od 15 do18 let. Manj je bi-

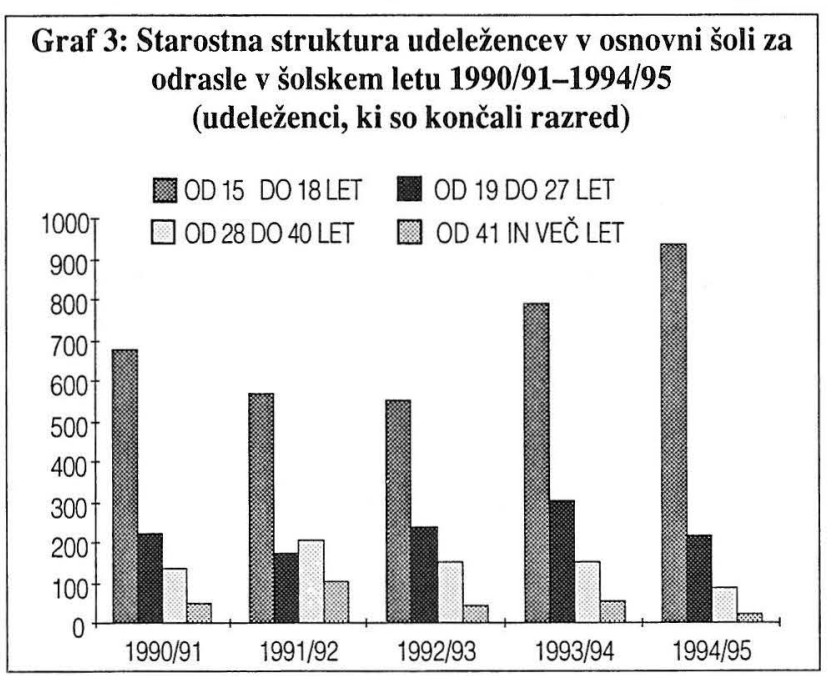

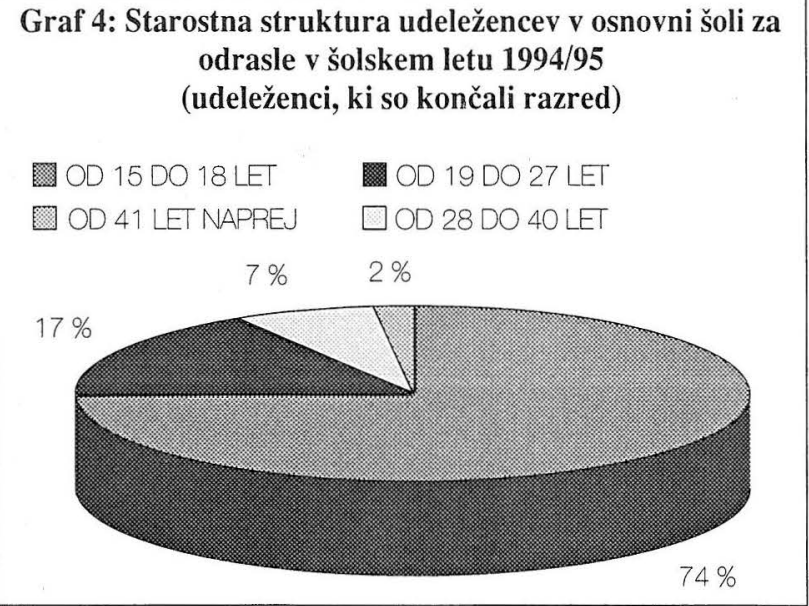

lo odraslih, starih od 19 do 27 let $-17 \%, 7 \%$ udeležencev je bilo starih od 28 do 40 let, $2 \%$ pa 41 let in več.

Več kot $50 \%$ vseh, ki končajo osnovnošolsko obveznost na ljudskih univerzah, kasneje nadaljuje šolanje po skrajšanih in srednješolskih programih. Za vpis v te programe pa je treba končati program tujega jezika po predmetniku, ki velja za redne osnovne šole. Tuj jezik po predmetniku osnovne šole za odrasle ni obvezen, čeprav poučujejo ta predmet na vseh ljudskih univerzah. Med prenovo bi bilo zato mogoče smiselno razmišljati o njegovi vključitvi v obvezen predmetnik za mlajše odrasle, ki se vključujejo v ta program.

\section{Učifelii v osnovnih šolah za odrasle}

Učitelji, ki poučujejo v osnovnih šolah za odrasle, so predvsem zunanji sodelavci, zaposleni po pogodbah in pomenijo $\mathrm{v}$ povprečju kar $91 \%$. Zelo malo je učiteljev, ki so zaposleni za določen oziroma nedoločen čas - graf 5.

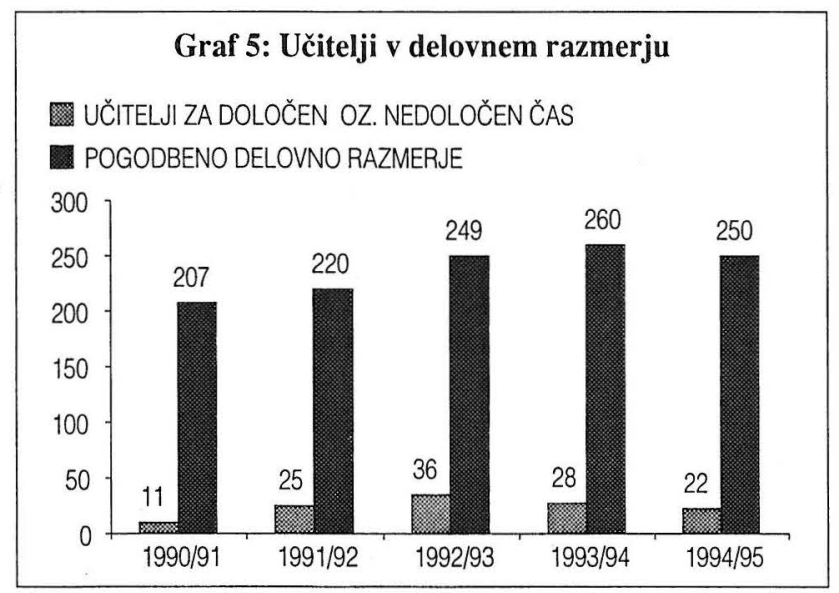

Na Zavodu za zaposlovanje je bilo v Sloveniji konec septembra 1996 prijavljenih 118.083 iskalcev zaposlitve, od tega jih je bilo 46.512 oziroma $39,39 \%$ z nedokončano osnovno šolo. Med temi je kar 12.343 ali $26,54 \%$ iskalcev, mlajših od 26 let. Delodajalci največkrat zaposlujejo iskalce zaposlitve brez dokončane osnovne šole za določen čas, po preteku določenega časa pa se ti spet znajdejo na zavodih za zaposlovanje. To je tudi populacija, ki ima zaradi hitrega razvoja tehnike in tehnologije, prestrukturiranja podjetij in čedalje večje brezposelnosti vse manj možnosti za zaposlitev in tudi za ohranitev dela, ki ga opravlja. To kaže, da je treba pri populaciji z nedokončano osnovno šolo povečati obveščenost in motivacijo. 
V novi šolski zakonodaji opredeljujeta osnovno šolo za odrasle Zakon o osnovni šoli in Zakon o izobraževanju odraslih.

Zakon o osnovni šoli določa, 93. člen, da osnovnošolsko izobraževanje odraslih poteka po programu osnovne šole za odrasle. Določa tudi, da se kot odrasli lahko izobražujejo tisti, ki so izpolnili osnovnošolsko obveznost in niso končali osnovnošolskega izobraževanja. Izobraževanje odraslih po tem zakonu poteka $\mathrm{s}$ prilagoditvijo organizacije, preverjanja, ocenjevanja, napredovanja in časovne razporeditve pouka.

V Zakonu o izobraževanju odraslih je določeno, da izobraževanje odraslih zajema tudi izobraževanje odraslih po programih osnovnošolskega izobraževanja in da je urejeno z zakonom za to področje izobraževanja ter s tem zakonom. Določa tudi, da izobraževanje odraslih temelji na naslednjih načelih:

- vseživljenjskosti izobraževanja,

- dostopnosti izobraževanja pod enakimi pogoji,

- svobodi in avtonomnosti pri izbiri poti, vsebine, oblik, sredstev in metod izobraževanja,

- laičnosti izobraževanja odraslih, ki se ga opravlja kot javna služba,

- strokovni in etični odgovornosti izobraževalcev,

- spoštovanju osebnosti in dostojanstva vsakega udeleženca in

- doseganju enakih standardov kot pri izobraževanju mladine.

Pri načrtovanju prenove programa osnovnošolskega izobraževanja je treba upoštevati Zakon o osnovni šoli in Zakon o izobra- ževanju odraslih, predvsem pa je treba dobro poznati razmere v osnovnih šolah za odrasle na ljudskih univerzah in upoštevati mnenja in predloge, ki izhajajo iz prakse. Pri vse večjem osipu v rednih osnovnih šolah, ne samo v VII. in VIII. razredu, temveč tudi v nižjih razredih, pri vse večji nezaposlenosti, nekonkurenčnosti na trgu delovne sile je treba program in organizacijo prenovljene osnovne šole nujno pripraviti tako, da bosta udeležencem čim bolj prilagojena in zanje zanimiva. Kajti znanje, ki ga ti udeleženci pridobijo, vpliva na njihov vsestranski razvoj in jim ne omogoča le vključevanja v nadaljnje izobraževanje in $\mathrm{s}$ tem uresničitve njihovih ciljev, temveč pripomore tudi k dvigu izobrazbene ravni in večji uspešnosti celotne družbe.

Diana Roškar

strokovna delavka na ZLUS

\section{Viri}

Zakon o izobraževanju odraslih.

Zakon o osnovni šoli.

Zavod RS za statistiko: Statistični podatki na osnovi obrazca ŠOL - LU in ŠOL $-O$.

Zavod RS za zaposlovanje: Pregled zaposlovanja in števila oseb, ki iščejo zaposlitev v mesecu septembru 1996.

Ministrstvo RS za šolstvo in šport: Statistični podatki za LU za šol. leto 1996/97 (jesenski semester). 